\title{
Contributions towards a Knowledge of the Anatomy of the genus Selaginella, Spr.
}

BY

R. J. HARVEY GIBSON, M.A., F.L.S.

Professor of Botany in University College, Liverpool.

\section{With Plate VIII.}

PART II. THE LIGULE.

THE present paper is the third of a series ${ }^{1}$ in which 1 I desire to record observations on the minute anatomy of the genus Selaginella, and deals more especially with the structure and development of the ligule.

Accounts of the structure and development of the ligule in Selaginella are few and far between. Russow ${ }^{2}$, in discussing the structure of the leaf in this genus, refers to the ligule merely as a means of distinguishing one leaf-face from the other,- that next the stem being 'ligular,' that away from the stem 'aligular.'

Treub ${ }^{3}$ says : 'Je n'ai pas étudié en detail la formation de la ligule,' and both Dangeard ${ }^{4}$ and Erikson ${ }^{5}$ ignore its

1 Annals of Botany, Vol. vii. No. xxvii, I 893, and Vol. viii. No. xxx, I894.

${ }^{2}$ Vergleichende Untersuchungen über Leitbündel-Kryptogamen. Mém. l'Acad. Imper. St. Pétersb. xix. 1872 .

${ }^{3}$ Les organes de la végétation du Selaginella Martensii, Spr. Leide, 1877 .

4 Essai sur l'anatomie des Cryptogames vasculaires. Le Botaniste, Vol. i, I889.

5 Bidrag till Kännedomen om Lycopodinebladens Anatomi. Arbet. fran Lunds Bot. Instit., I892.

[Annals of Botany, Vol. X. No. XXXVII. March, 1896.] 


\section{Gibson.-Contributions towards a Knowledge of}

existence altogether. Hofmeister ${ }^{1}$ gives by far the fullest account of the development of the ligule. His observations were made chiefly on S. denticulata, Spr., and S. Galeottei, Spr. $\mathrm{He}$ describes it as arising from a double row of cells at the base of the young leaf, just in the angle between the leaf and the stem. These cells remain larger than the neighbouring cells, and have their free walls curved outwards. By alternate oblique segmentation of the cell lying further from the stem, there comes to be formed a ridge of cells with an apical merismatic region lying at right angles to the long axis of the leaf and close to its base. Longitudinal and transverse divisions follow, so that the body of the ligule becomes several layers thick. Terminally the ligule is only one layer of cells in thickness, and is fringed with unicellular papillae. The cells by which the ligule is sunk in and attached to the leaf-base remain always as two parallel rows. Hofmeister describes the cells of the ligule as containing a granular colourless slime, and as being destitute of chlorophyll. He also draws attention to the very transitory vitality of the ligule, and to the fact that the development of the ligule is concluded long before that of the leaf to which it belongs. These two observations seem to be of great importance as bearing on the probable homologies and functions of the ligule: to this, however, I shall refer later on.

Pfeffer ${ }^{2}$, in tracing the development of the embryo in $S$. Martensii, makes a brief reference to the mode of origin of the ligule. He describes it as arising from a single row of four to six cells, not from a double layer, as described by Hofmeister; but his account of the further development agrees substantially with that of Hofmeister.

$\mathrm{McNab}{ }^{3}$ draws attention to the expansion of the leaf-trace bundle beneath the base of the ligule, and suggests that the ligule is an organ of absorption.

${ }^{1}$ Vergleichende Untersuchungen der Entwicklung höherer Kryptogamen. Leipzig, I 85 I.

${ }^{2}$ Die Entwicklung des Keimes der Gattung Seiaginella. Hanstein's Bot. Abhandl. I87i.

3 The Stomata and Ligules of Selaginella. Brit. Assoc. Rep. 1887. 
Farmer ${ }^{1}$ contrasts Selaginella with Isoetes in regard to the structure and development of the ligule, and points out that in the former the ligule is multicellular in origin, whilst in the latter it is unicellular. He further remarks that 'the mature structure of the ligule is not nearly so complete as in Isoetes, especially as regards its insertion.' My observations on the ligule of Selaginella scarcely bear out this view. The ligule, Farmer states, is developed much later in Selaginella than in Isoetes.

Bower ${ }^{2}$ gives no description of the development of the ligule, but in his figures illustrating the development of the sporangium he gives certain data worthy of comment: his Fig. 79 (Pl. 47) shows a primary stage in the development of the ligule of $S$. Martensii, where two shaded cells (in longitudinal section) indicate its point of origin, whilst Figs. 84, 85, 86,87 , and 89 illustrate stages in the development of the ligule of S. spinosa, to which I shall have occasion to refer later. Professor Bower has been so kind as to place his preparations at my disposal for comparison with my own, and I may say that they fully bear out his figures.

Campbell ${ }^{3}$, in his recent work on Mosses and Ferns, gives a brief reference to the ligule in S. Kraussiana, and speaks of it as 'much constricted at the point where it joins the leaf.' His figure (Fig. 261), moreover, shows the sheathing-cells of the glossopodium not continuous with the epidermal-cells, but quite outside them.

It will be seen from this short summary that our knowledge of the variations in the adult form of the ligule and its comparative development in different species is, to say the least, meagre; whilst we have conflicting accounts of its mode of development in the works of Pfeffer and of Hofmeister, the former describing it as arising from one row of cells in S. Martensii [' wie bei diesen ensteht am Grunde der Innenseite der Kotyledonen eine Ligula, an deren Bildung ich immer

1 On Isoetes lacustris, L. Annals of Botany, Vol. v, I89o.

${ }^{2}$ Studies on the Morphology of spore-producing Members. Phil. Trans. I 894.

3 The Structure and Development of Mosses and Ferns. Macmillan \& Co. I895. 


\section{Gibson.-Contributions towards a Knowledge of}

nur eine einfache . . . Reihe von vier bis sechs Zellen Theil nehmen sah'], whilst the latter believes it to arise in $S$. denticulata and S. Galeottei from two rows of cells. It may be noticed at this point that Bower's figures for $S$. Martensii show two rows of cells in longitudinal section, not one as described and figured by Pfeffer.

In the present paper I have endeavoured $(\alpha)$ to give a general and comparative account of the form and adult structure of the ligule, employing for that purpose alcoholic material of over fifty species, $(b)$ to describe the chief stages in the development of the ligule in a few selected types, and $(c)$ to hazard such suggestions as to the homologies and functions of the ligule in the genus as seem to me to be borne out by the data I have endeavoured to collect.

\section{A. Adult Structure of the Ligule.}

The ligule, in the majority of the species which I have examined, arises just at the junction of the stem and leafbase, but distinctly from the leaf. In forms like $S$. oregana (Fig. 19), S. rupestris ${ }^{1}$, \&c., however, the ligule is seated in a deep pit in the leaf-base, and with a well-marked swollen region intervening between it and the stem, so as to suggest in some measure the foveola and ligule of Isoetes, and the very deep-seated 'ligules' of allied fossil forms.

Generally speaking, the ligule varies in outline from a short, somewhat rectangular plate, whose free distal margin may be more or less fringed with unicellular papillae, as in S.Douglasii, S. stenophylla, S. suberosa, S. molliceps, S. cuspidata, \&c.; or simply crenate, as in S. erythropus (Fig. I6), S. serpens, S. involvens, \&c.; to a distinct fan-shaped body, also with crenate, lobed, or papillate margin, as in S. grandis (Fig. I4), S. haematodes, S. caulescens, S. Karsteniana, S. viticulosa, S. plumosa, \&c. In S. Martensii (Fig. I3), perhaps the most perfect fanshape is attained, the free distal margin being curved and about twice the breadth of the ligular base. Considerable

\footnotetext{
${ }^{1}$ In the naming of the species I have, as in previous papers, followed Baker's Fern Allies.
} 
variation occurs in the precise form of the ligule, even in the same plant; but, on the whole, within certain limits, the outline is maintained fairly constantly for the species. In S. Vogelii (Fig. I 5), S. Griffithii, S. uncinata, \&c., the ligule is tongue-like and slightly crenate, without papillae.

The ligule is sunk in the tissue of the leaf-base by a more or less massive glossopodium, bearing an intimate relation to the cells of the leaf-base. In $S$. haematodes, for example, the glossopodium is scarcely at all sunk, whilst in S. helvetica (Fig. 17), S. laevigata, var. Lyallii (Fig. 21), and others, the ligule has a deep and well-marked glossopodium fitting into a distinct cup in the leaf-base. In all the species which I have examined, the glossopodium is enclosed by a distinct sheath of cells which are obviously continuous with the epidermal cells-on the one side, of the leaf, on the other, of the stemand which are either cubical or elongated in the plane of the long axis of the leaf. These cells, when the ligule reaches a certain age, become strongly cuticularized and thick-walled. The base of the ligule itself, or glossopodium, is composed of specially large and clearly-marked cells with little contents. Where there are two rows of these, they are not unlike right triangular prisms with the long faces towards the sheath. The glossopodium as a whole may be looked upon as a blunt wedge, thick in the middle and thinning away rather abruptly to either margin. The wedge at its thickest part may be two, three, four or even more cells thick. Thus in S. Martensii, S. grandis, S. Vogelii, S. Griffithii, \&c., there appear generally two such basal cells in any given section taken in the median longitudinal plane of the leaf; in S. Douglasii, S. Karsteniana, $S$. viticulosa, $S$. helvetica, \&c., three such cells appear, the median cell being cubical or brick-shaped; whilst in S. Braunii there are four or even more such cells (Fig. I2). The primary number does not seem to me to be in all cases maintained, secondary divisions occurring as the ligule grows older. For instance, in S. spinosa the ligule has three initial cell-rows, which may, however, by division become four or even more (Figs. I, 2, 4, 6). 


\section{Gibson.-Contributions towards a Knowledge of}

Following upon the glossopodium comes a thicker swollen region whose cells are large, polygonal, and filled with dense granular protoplasm, with well-marked nuclei (Fig. 8). The long axis of the glossopodium is not in the same plane with that of the long axis of the body of the ligule, but cuts it at a more or less pronounced oblique angle, the glossopodium pointing away from the stem into the base of the leaf, while the free portion of the ligule lies almost parallel with the leafblade. The distal half of the ligule consists of smaller and less granular cells, and thins off to the free margin, which is unilamellar in the adult condition, the cells there being more or less filled with a granular slime. I purpose referring to these cells later on.

Between the glossopodial sheath and the leaf-trace-bundle there lie one to several layers of large cells, which radiate from the glossopodium outwards towards the leaf and inwards towards the stem. In most cases these cells retain their cellular character, or at most become slightly thickened and pitted; but in many they become markedly thickened, and in the mature condition are transformed into short, often branched tracheidęs. In S. apus, S. stenaphylla, S. Martensii, and others, only a few such secondary tracheides with scalariform markings are formed, so that the leaf-trace appears only slightly enlarged just beneath the glossopodium; but in $S$. helvetica these tracheidal elements are so numerous that the whole glossopodium is enclosed in a distinct cup-like vascular enlargement. An intermediate condition may be seen in such a form as $S$. Wildenowii, whilst S. laevigata, var. Lyallii, shows the greatest development of tracheides of any of the species I have examined. In that species (Fig. 2I) a very distinct vascular cup is formed, which shows up very clearly if the ligule be carefully pulled out of its socket after boiling the portion of the shoot selected in dilute potash. This curious expansion of the leaf-trace, if it may be so termed, has already been noted by $\mathrm{McNab}$ (l.c.), and he doubtless based his theory of the absorptive function of the ligule on this fact. I think, however, that the phenomenon in question 
is capable of another interpretation, which perhaps more satisfactorily meets the case.

The sheathing-cells of the glossopodium vary much in shape. Most frequently, as in S. grandis, S. Martensii, S. caulescens, $S$. viticulosa, \&c., they are in the form of elongated staves or bars, curving round to meet at what may be termed the base of the foveola; whilst in other cases, e. g. S. spinosa, they are short cubes.

The ligule of S. oregana (Fig. I9) and S. rupestris deserves a word of explanation. In these species the free margin of the ligule scarcely appears above the edge of the very deep pit in the leaf in which it is seated. The vascular bundle of the leaf does not present any enlargement, but the radiating cells intervening between it and the sheath of the glossopodium are strongly sclerotic. The sheath consists of two rows of stave-like cells, and the glossopodium of two rows of right triangular prisms. The leaf-tissue, however, grows up and round the free portion of the ligule, so that a deep pit is formed, the cells of which have no connexion with the ligule. These appearances are illustrated in Fig. I9.

\section{B. The Development of the Ligule.}

In tracing the development of the ligule, I confined myself to the study of the shoots of two species, viz. S. spinosa and S. Martensii; partly because I had the advantage of comparing my own preparations with the large series kindly lent me by Professor Bower, and partly because, from an examination of the adult state of the ligule in numerous species, I felt that the differences in mode of development were unlikely to be very fundamental.

S. spinosa. The ligule, as in all the species of this genus, is multicellular in origin. If careful longitudinal sections be made of the growing-point, the ligule may be distinguished first about the level of the third or fourth leaf as a fairly distinct swelling immediately at the base of the leaf. The swelling consists of a short ridge about six or eight cells in length in the plane of the leaf-face, and three broad, that is to say, 


\section{Gibson.-Contributions towards a Knowledge of}

in the plane at right angles to the ridge. Fig. I shows the earliest distinctly recognizable stage in the development, the left-hand side of the figure representing the surface of the stem, whilst the leaf-face is partly shown on the right. The ridge is shown here as three cells broad, and these cells may be distinguished very early, not only by their greater size, bulging out into the angle between the leaf and the stem, but also by the fact that they take on a deeper stain than do the surrounding cells, and have larger nuclei. At the margins the ridge is only one cell broad. These cells speedily undergo transverse division, so that a basal sheath of cubical cells (Figs. 2, 3, and 4) is formed continuous with the epidermis of the leaf and stem, the free segments growing outwards to form the ligule itself. The sheath-cells may undergo further divisions, as shown in Figs. 3 and 6, and the cells of which it is composed at a later date become thick-walled and cuticularized. The next layer of cells from the merismatic prominence gives rise to the glossopodium; these cells enlarge greatly, and do not stain so deeply as the sheathing-cells or those of the body of the ligule, whilst the general cells of the body of the ligule remain as a rule of much smaller size.

The ligule has completed its development long before the leaf to which it belongs; indeed, it has reached its adult size and shape at a distance of from $I$ to $I \frac{1}{2} \mathrm{~mm}$. from the apex of the shoot. Occasionally the clearer basal cell-layer or glossopodium becomes four cells broad (Fig. 6), but three is by far the commoner number. The body of the ligule itself may, however, be six or even more cells thick. Fig. 5 shows a transverse section of the ligule in a comparatively young condition, while in Fig. 6 a longitudinal section of an adult ligule shows it to be composed of five cell-rows.

S. Martensii. Pfeffer (l.c.) describes the ligule of S. Martensii as arising from one row of from four to six cells. I have made careful examinations of longitudinal sections of very many growing apices, and find no evidence in support of his statement or figure. The ligule appears to me to arise invariably from two rows of cells (Fig. 7), which can easily be 


\section{the Anatomy of the gemus Selaginella, Spr. 85}

distinguished both by their greater size and more granular and denser protoplasm, as well as by their conspicuous bulging into the angle between the stem and leaf. In this view I am supported by Bower's figures illustrating the development of the sporangium (l.c. Pl. 47, Fig. 79). As in S. spinosa, the two primary cell-rows undergo transverse segmentation, so as to isolate a set of sheathing-cells surrounding the foot of the ligule. The outer cell-segments then separate another set of large comparatively empty cells, which grow in size as the ligule develops. Rapid segmentation of the apical region then takes place so as to form a thick swollen portion, which later becomes two-layered, and finally ends in a unilamellar apical plate. In the ligules of the vegetative leaves the sheathing and the glossopodial cells remain in two rows, but in the ligules associated with sporangia both sheathing and glossopodial cells may divide so as to form three rows, at all events in the thicker median region of the ligule.

All the observations I have made on the development of the ligules of other species point to a similar embryonic history, and I feel convinced that the number of cell-rows in the adult glossopodium will give a fairly reliable indication of the number of primary merismatic cell-rows which take part in the formation of the ligule, though doubtless secondary divisions may occur in these, as I have already pointed out in S. spinosa.

\section{The Function of the Ligule.}

The homologies and functions of the ligules in the genus Selaginella have for long been matters of controversy. It has been suggested, for instance, that the ligule may be of the nature of an indusium, a view against which many and obvious objections may be raised. $\mathrm{McNab}$ (l.c.) considered it as an organ of absorption, basing his conclusion on the close association of the ligule with the vascular bundle of the leaf. A homology between the ligules of Selaginella and of Isoetes has been made much of by many writers, and has, as is well known, been employed as a basis of classification; but, as 
Farmer says, "the relationship between the two is at the best but very remote, so different are they in all other important characters; to endeavour, therefore, to unite them on account of the presence of a ligule in each of them, even if this structure were more similar in the two plants than as a matter of fact is the case, is like an attempt to establish an affinity between Rosaceae and Cupuliferae on the ground that stipules are common to both orders.'

My own view of the homology of the ligule in Selaginella is briefly that it is a specialized ramentum, such as one finds so commonly in the Pteridophyta and in the Hepaticae. I base this conclusion on certain facts with regard to the structure and development of the ligule itself. In the first place, the ligule is developed very early in the history of the leaf, and is fully developed long before the leaf to which it belongs has reached maturity. Farmer affirms that the ligule in Selaginella is much later in development than in Isoetes (l. c., p. 45). I have not examined the development of the ligule of Isoetes, but comparison of Farmer's drawings and my own sections of the growing-point of Selaginella does not seem to me to bring out any well-marked difference between the two structures in this relation. The apical bud in Selaginella is very dense, and the leaves are very closely packed, the whole growing region being extremely short. It is true that the ligule is comparatively small as compared with even the young leaf; but the close packing of the leaves may, and probably does, very materially aid in protecting the growing-point from desiccation. Farmer draws attention to the same fact in Isoetes lacustris, where 'the ligule is, comparatively speaking (with $I$. velata), but little developed, and there is, moreover, in this plant no apparent need of special protection, especially as the older leaves so securely shelter the younger ones.'

Then again the vascular bundle to the leaf runs in close relation to the glossopodium, and may, as has been shown above, form a more or less distinct cup of tracheides around it. An adequate supply of water to the ligule is thus provided for. 
The marginal papillae of the ligule are, in the young state, filled with mucilage, and stand out prominently when treated with Bismarck-brown. Further down the axis, and after the leaves have reached their maximum development, the ligule undergoes considerable change. The cells to a great extent lose their contents, and, as I have already shown, become thicker-walled and cuticularized, cutting off the ligule in consequence from further water-supply.

All the facts in connexion with the ligule point, I think, to the function being a temporary one, viz. to act as an organ for keeping the growing-point and the young leaves moist. In this respect the ligules of Selaginella and Isoetes may be quite reasonably compared. Indeed from a morphological point of view also the ligules of these two genera seem to be merely specialized types of ramentum, although they do not necessarily form a ground for believing in the close phylogenetic relationship of genera otherwise so distinct.

\section{EXPLANATION OF FIGURES IN PLATE VIII.}

Illustrating Professor Harvey Gibson's paper on Selaginella.

S. spinosa, P. B.

Fig. I. Longitudinal section through the growing-point of S. spinosa. $\times 350$. The initial cells of the ligule are shaded.

Fig. 2. Longitudinal median section of a half-grown ligule. $\times 35^{\circ}$. The sheathing-cells are shaded and have subdivided.

Fig. 3. Face view (tangential section) of a ligule slightly older than that represented in Fig. 2. The sheathing cells are seen end on; the glossopodial cells, eight in number, are followed by the densely granular cells of the body of the ligule. $\times 35$.

Fig. 4. Longitudinal median section through a ligule at a stage of development halfway between those represented in Figs. I and $2 . \times 35^{\circ}$.

Fig. 5. Transverse section through the body of a ligule at the stage represented in longitudinal section at Fig. $2 . \times 35^{\circ}$.

Fig. 6. Longitudinal section through the base of an older ligule, showing the thickened walls of the sheathing cells. $\times 350$. 


\section{Gibson.-Anatomy of the gemus Selaginella, Spr.}

\section{S. Martensii, Spr.}

Fig. 7. Longitudinal section through the growing-point of S. Martensii. $\times 35^{\circ}$. The initial cells of the ligule are shaded.

Fig. 8. Longitudinal section through an almost mature ligule. The narrow sheathing cells, three in number in section, are followed by three glossopodial cellrows; the body of the ligule is composed of an irregularly arranged mass of densely granular cells, followed by the membranous terminal lamella. $\times 35^{\circ}$.

\section{S. Braunii, Bak.}

Fig. 9. Longitudinal median section of a very young ligule of S. Braunii. Four rows of initial cells are represented. $\times 350$.

Fig. Io. Longitudinal section of a slightly older ligule of the same. $\times 35^{\circ}$.

Fig. I I. Transverse section of the base of a young ligule, taken just above the glossopodium. $\times 35^{\circ}$.

Fig. I 2. Longitudinal section of an old ligule. The sheathing and glossopodial cells are arranged in four rows. $\times 35^{\circ}$.

Fig. I3. Ligule of S. Martensii, Spr., isolated from its sheathing-cells. $\times 60$.

Fig. I 4. Isolated ligule of $S$. grandis, Moore. $\times 60$.

Fig. 15. Isolated ligule of $S$. Vogelii, Spr. $\quad \times 60$.

Fig. 16. Isolated ligule of $S$. erythropus, Spr. $\times 60$.

Fig. I 7. Longitudinal median section through an old ligule of S. helvetica, Lk., showing the thick-walled sheathing cells and the enlargement of the vascular bundle of the leaf to form a tracheidal cup round the glossopodium. $\times 350$.

Fig. I 8. Transverse section through the glossopodial region of an old ligule of S. flabellata, Spr. $\times 35^{\circ}$.

Fig. I9. Longitudinal median section through the ligule and leaf-base of S. oregana, Eat. $\times$ I50. There are two rows of sheathing and of glossopodial cells, the entire ligule being depressed and almost hidden in an involution of the leaf-base.

Fig. 20. Longitudinal median section of the base of a mature ligule of S. grandis, Moore. $\times 35^{\circ}$.

Fig. 2 I. Longitudinal median section of the ligule of $S$. laevigata, Bak. var. Lyallii, Spr., showing the enlarged tracheidal cup surrounding the base of the ligule. $\times 150$. 
Annals of Botany.

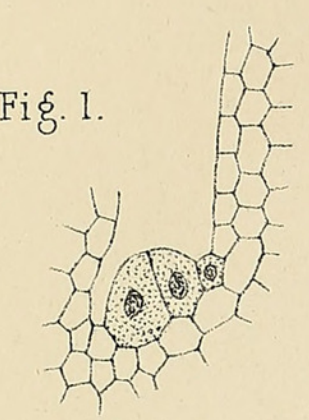

Fig. 3.

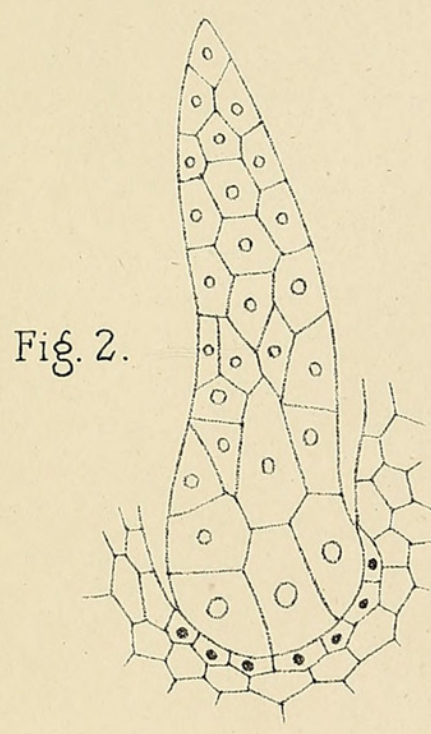

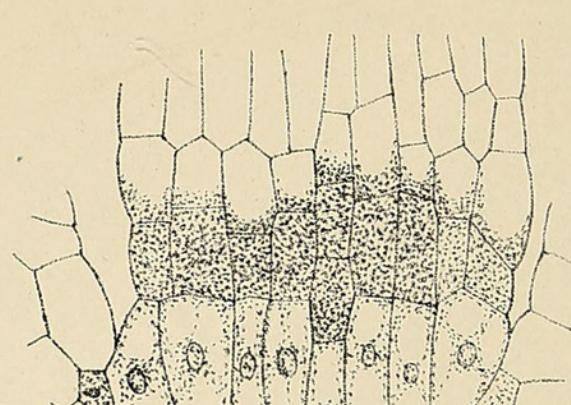

3. 0601010

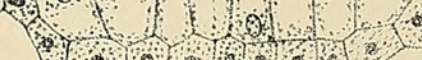

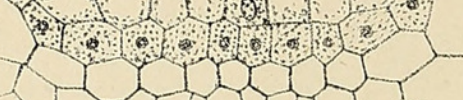

जितारता

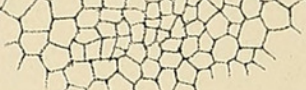
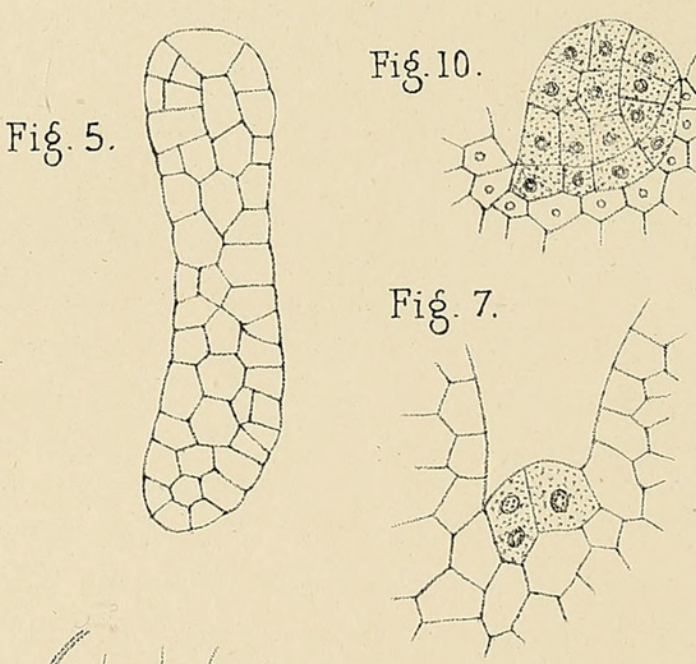

Fig. 15 .

Fig. 4.
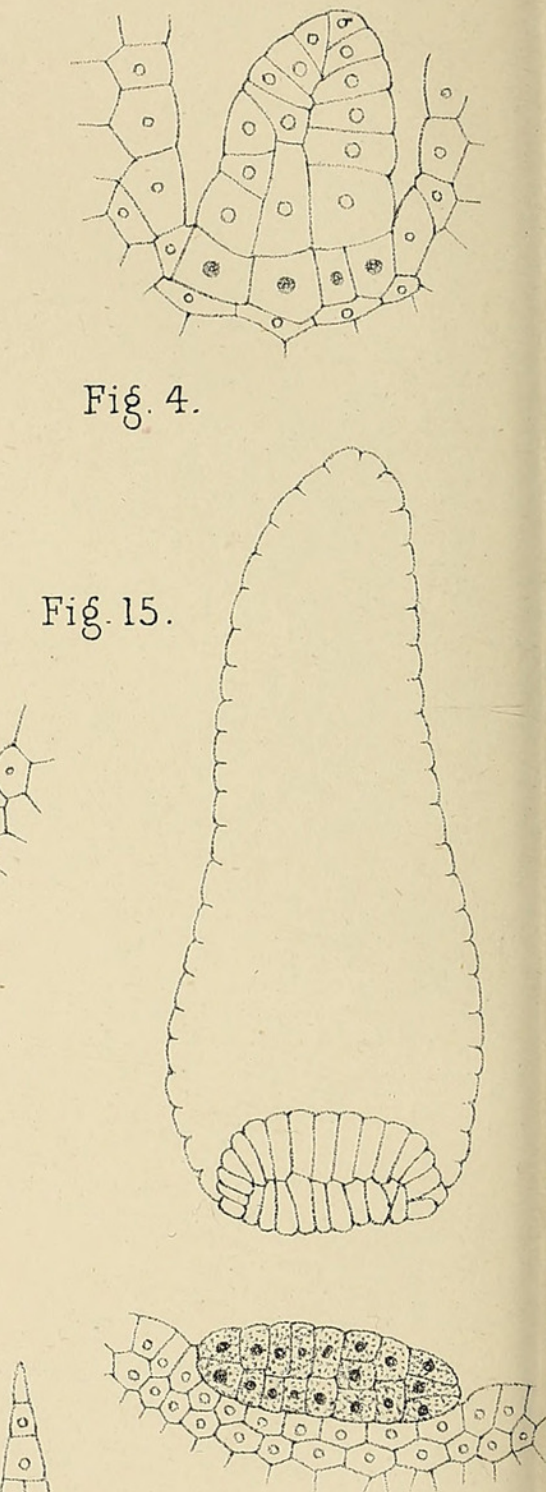

Fig. 11.

Fig. 12 .
Fig. 9.

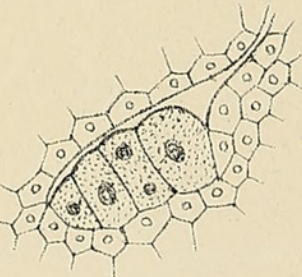

Fig. 8 .

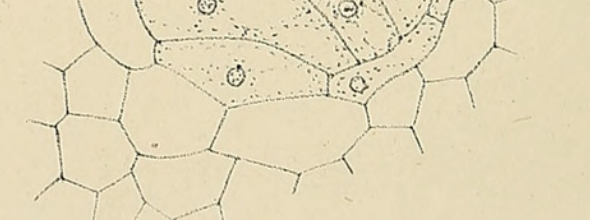

\section{R.J H G del.}




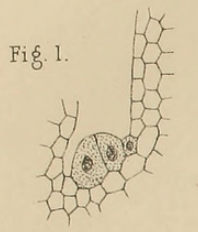
Fis. 3.

Fis. 3.
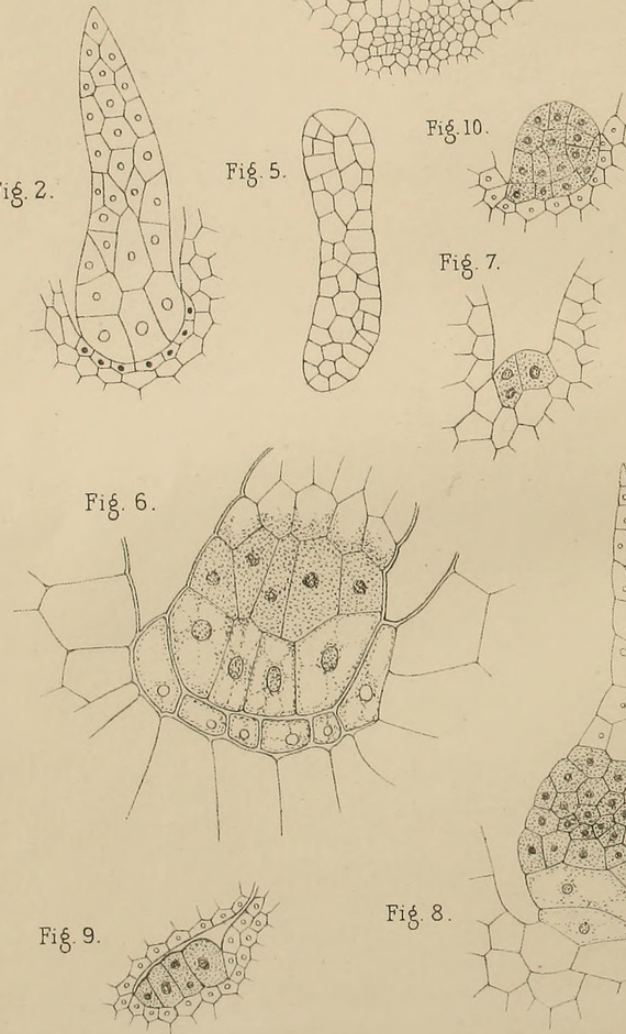

Fig. 8.

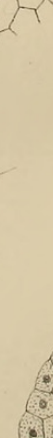

Fig. 15.

Fig. 4.
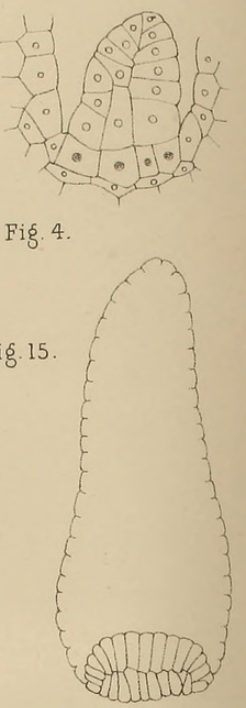

Fiø. 1

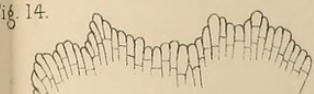

Fig. 17.
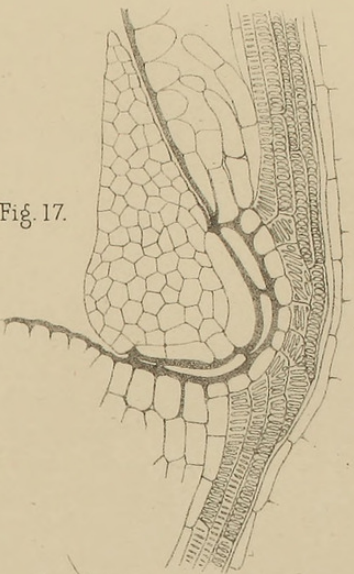

Fig. 19.
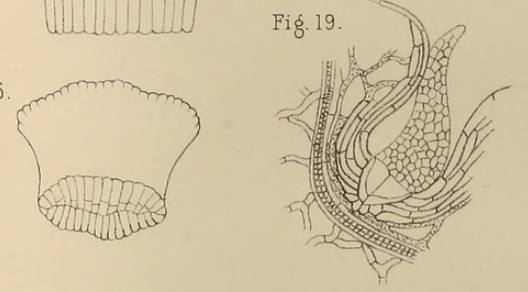

Fiß. 11.

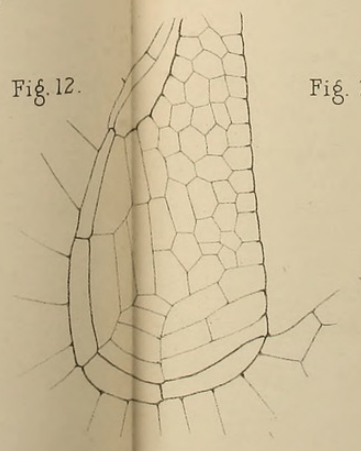

Fig. 21.

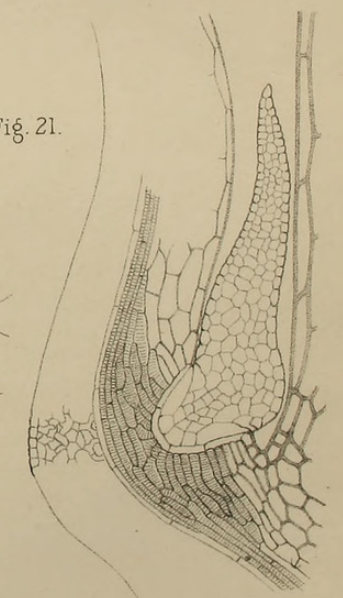

University Press, 0xford 


\section{$2 \mathrm{BHL}$ Biodiversity Heritage Library}

Harvey-Gibson, R. J. 1896. "Contributions towards a knowledge of the anatomy of the Genus selaginella, Spr." Annals of botany 10, 77-88. https://doi.org/10.1093/oxfordjournals.aob.a088600.

View This Item Online: https://www.biodiversitylibrary.org/item/235772

DOI: https://doi.org/10.1093/oxfordjournals.aob.a088600

Permalink: https://www.biodiversitylibrary.org/partpdf/318409

\section{Holding Institution}

Smithsonian Libraries

\section{Sponsored by}

Biodiversity Heritage Library

\section{Copyright \& Reuse}

Copyright Status: Not in copyright. The BHL knows of no copyright restrictions on this item.

This document was created from content at the Biodiversity Heritage Library, the world's largest open access digital library for biodiversity literature and archives. Visit BHL at https://www.biodiversitylibrary.org. 